borrowed elements from the open-source software movement to develop a public agreement for designers of syntheticbiology parts. But the 708 parts in the BioBricks open-source collection come from only three donors: DNA2.0, Endy and Ginkgo BioWorks, a synthetic-biology company in Boston, Massachusetts. Commercial use of some of the highest-impact parts is still kept under lock and key by industry or academic labs.

Mark Fischer, a copyright lawyer at Duane Morris in Boston, and a key architect of the BioBricks agreement, says that that DNA2.0's contribution to the registry is a sign that the movement is taking off. "I think we're now at the dawn of that happening," says Fischer, who also helped to pioneer open-source software agreements.

The open-source push in synthetic biology has also rekindled talk of copyrighting engineered DNA sequences. Copyrights protect certain types of work from being reproduced without permission, but users may substantially modify those creations. The United States started granting such protections to computer programs in the 1960s.

DNA2.0 plans to find out whether DNA sequences can also be shoehorned into the framework. Last year, the company petitioned for US copyright protection of the DNA sequence for a fluorescent green protein, without success, but has launched an appeal. Its plan, says Christopher Holman, a law professor at the University of Missouri-Kansas City who is working with DNA2.0, is to pursue the appeal until the issue is heard in court.

Copyrights are cheaper, easier alternatives to patents, says Endy. They cost $\$ 35$ to register, as opposed to the $\$ 100,000$ in legal fees and administrative costs that DNA2.0 says it pays for each patent application it files. But Endy worries about the duration of copyright protections, which can last up to 120 years; patents, by contrast, expire after 20.

And patents are still useful for some inventions, says Gustafsson. DNA2.0 will continue to patent some of its engineered tem as everyone else," says Gustafsson. "But we also want to increase our market size." it is too soon to judge the project. He says genes and proteins. "We play in the same sys-

\section{US Senate backs immigration plan}

\section{Proposal would lift visa caps for US-trained scientists and engineers.}

\section{BY HELEN SHEN}

$\mathrm{F}$ or Gaurav Basu, a graduate scholarship in 2003 helped to fulfil a long-held ambition of pursuing scientific research in the United States. In 2009, Basu, a native of India, earned his $\mathrm{PhD}$ in biomedical sciences from Eastern Virginia Medical School in Norfolk.

But Basu is struggling to keep his American dream alive after finishing a postdoctoral fellowship at Old Dominion University in Norfolk in 2011. With his temporary work visa set to expire in 2015, he is now working as a consultant in northern Virginia - and fighting tough odds to stay in the United States permanently by applying for a coveted but scarce 'green card'.

Those green cards could soon flow more freely to scientists such as Basu. After years of debate and many failed attempts, on 27 June the US Senate approved a comprehensive immigration plan that would allow thousands more foreign scientists and engineers to remain in the United States permanently. "It's a phenomenal improvement over the current situation," says Russell Harrison, a senior legislative representative for IEEE-USA in Washington DC, which advocates for US members of the Institute of Electrical and Electronics Engineers.

Under current policy, the number of green cards that can be issued each year is limited to 140,000 , a figure that is further reduced by percountry caps. Applicants from countries that send large numbers of immigrants - such as China, India, Mexico and the Philippines must often wait for years, subsisting on a string of temporary work visas that can be revoked at an employer's discretion.

"Our system is absolutely, utterly broken," says Amy Scott, associate vice-president for federal relations at the Association of

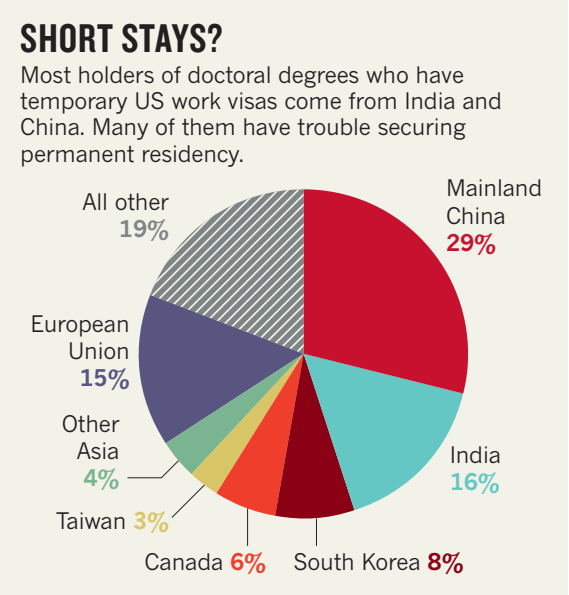

American Universities in Washington DC.

The Senate bill would end country-based caps and exempt researchers in some disciplines from limits altogether. Applicants with master's or doctoral degrees in science, technology, engineering or mathematics (STEM) obtained from US universities would be eligible to tap an unlimited pool of green cards. And, unlike previous proposals, the bill brings biological and biomedical sciences under the STEM umbrella.

According to the most recent statistics from the National Science Foundation, about 25\% of the US science and engineering workforce comes from other countries. People from China and India made up nearly half of $\mathrm{PhD}$ holders who received temporary work visas in 2009 (see 'Short stays?'). And many of them lead tenuous lives in their adopted country.

Among them is Somiranjan Ghosh, a senior research associate in molecular genetics at Howard University in

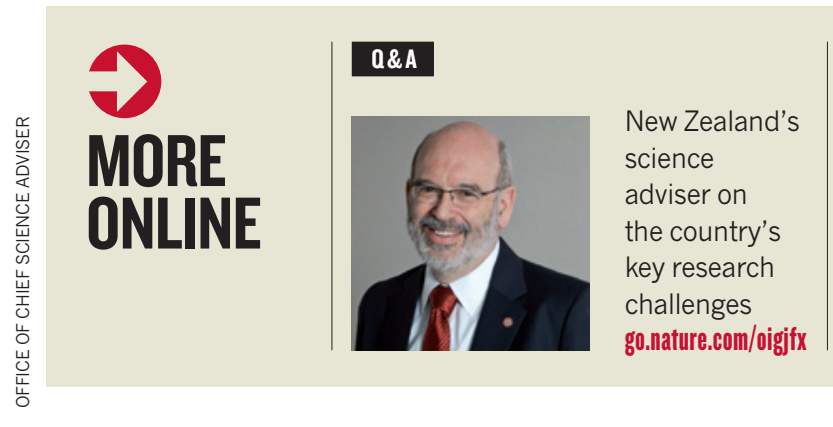

\section{NEWS}

- Voyager 1 is going, but not quite gone, from the Solar System go.nature. com/mugdvh

- 'Corkscrew' light could turbocharge the Internet go.nature.com/vyxfof - Water flow tracks earthquake healing go.nature.com/blla4e

\section{PODCAST}

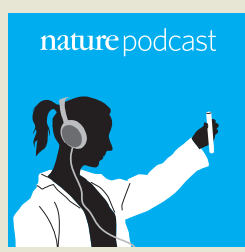


- Washington DC. Ghosh came to the United States from India in 2003 for a postdoctoral fellowship at the National Cancer Institute in Bethesda, Maryland, and finished a second fellowship at Howard University in 2007. He applied for permanent residency in December 2010 and was approved in 2011, but he has yet to receive his green card.

Ghosh also wants to travel abroad, but, without a green card, he could encounter administrative delays when he tries to re-enter the United States. Last year, he turned down an invitation to speak at a conference in France.

Worries about conference travel are a big problem for many postdoctoral fellows on temporary visas, says Benjamin Corb, director of public affairs at the American Society for Biochemistry and Molecular Biology in Rockville,

Maryland. “They just don't go, so they lose out on that opportunity in their professional career," he says. That understandable caution can also exact heavy personal costs. Ghosh was too afraid to return to India to see his sister before she died of cancer in January.

Ghosh's visa, unlike

\section{"Our system is absolutely, utterly broken."} a green card, does not allow him to change jobs easily. He would like to move into the field of medical diagnostics and eventually start his own company. "I'm 45 now," he says. "I want to start my own career."

Hopes of clearing the green card logjam now rest with the Republican-controlled House of Representatives, and its leaders are preparing separate proposals to address immigration.
Although increased immigration for scientists and engineers enjoys broad bipartisan support, Republicans argue that STEM green cards should be created only at the expense of other categories, such as the annual green card lottery for natives of countries that send few immigrants to the United States. But Democrats, who control the Senate, reject that notion. Any changes to the visa system will require agreement by both sides on a broader suite of hotly contested immigration issues.

For Basu, the stakes may be higher than for most. He and his wife are expecting their first child in three weeks, and he worries that the family may ultimately have to move back to India - away from the life they have created in Virginia. "Our kid will be an American citizen," says Basu. "We have roots here." -

\section{European deal cuts red tape}

\section{Horizon 2020 research programme streamlines project reimbursements.}

\section{BY QUIRIN SCHIERMEIER}

A deal struck last week during negotiations on the research programme for the next seven years in the European Union (EU) promises a significant change to the way in which institutions are reimbursed for the overhead costs of their research. The agreement for Horizon 2020 sweeps away the onerous red tape involved in the present diverse arrangements and replaces it with an acrossthe-board 25\% reimbursement rate for all.

Although the deal could be a boon for the many European universities with low overheads, which include heating, lighting, rent and facilities maintenance, it has disappointed some operators of large research facilities, mainly those in Western Europe. They warn that the simplified funding rules could harm top-ranking centres with high overheads because they will need reimbursement beyond $25 \%$ of the total direct costs.

"The new rules threaten to make Horizon 2020 extremely unattractive, particularly for research organizations dedicated to innovation," says Reimund Neugebauer, president of the Fraunhofer Society, headquartered in Munich, Germany, which carries out contract research for industry.

Details of Horizon 2020, due to start next January, have been under negotiation since February in a series of talks between EU member

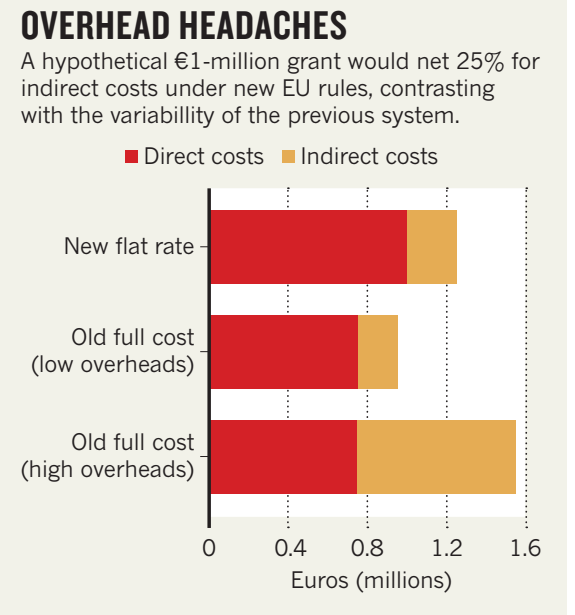

states, the European Parliament and the European Commission. The three were united on the programme's goal to spur economic growth and on its broad themes, which include health and energy research. But the parliament and member states have been squabbling over what accounting rules might best serve Europe's paperwork-plagued research community. The United States, too, has stumbled over funding of indirect costs (see 'Transatlantic concerns'), but some had feared that the European deadlock over the issue would delay the start of Horizon 2020

Keen to simplify the affair, the European Commission and most member states threw their support behind a system that would pay grant-winners the full direct costs of a project, such as salaries, travel and laboratory supplies, plus a $25 \%$ flat rate to cover overheads. Such a move would also please the EU's auditors - in a report released on 7 June, they slammed the complex funding model used in the organization's 2007-13 research programme.

But some Members of the European Parliament (MEPs) - backed by the European University Association in Brussels, which represents many of Europe's universities and research institutes - held that such an approach would make participation in Horizon 2020 unattractive for institutions with high overheads. Universities that run expensive facilities, for example ocean-going research vessels and synchrotron machines, would be left out of pocket, as would organizations such as the Fraunhofer, which have high overheads because the contract research they carry out often involves the use of expensive industryowned research facilities.

Critics of the flat rate were pushing for the 'full cost' reimbursement model used in the last EU research programme. This would have allowed organizations to get $75 \%$ of their direct costs plus $100 \%$ of their indirect costs which can sometimes be as high as the direct costs (see 'Overhead headaches'). In the end, a majority of member states and the commission gained the upper hand in their attempt to simplify the accounting. At the meeting last week, MEPs reluctantly agreed that Horizon 2020 would use only the flat-rate model. The deal must still be formally approved by 